\title{
A Study on Genetic Variability, Character Association and Path Co-Efficient Analysis on Morphological and Yield Attributing Characters of Taro [Colocasia esculenta (L.) Schott]
}

\author{
Dipaloke Mukherjee ${ }^{1}$, Md. Abdur Roquib², Nanda Dulal Das², Soma Mukherjee1 \\ ${ }^{1}$ Department of Food Science, Nutrition and Health Promotion, Mississippi State University, Starkville, MS, USA \\ ${ }^{2}$ Department of Plant Breeding, Bidhan Chandra Krishi Viswavidyalaya, Mohanpur, India \\ Email: *dipaloke.mukherjee@gmail.com
}

Received 25 January 2016; accepted 14 March 2016; published 17 March 2016

Copyright (C) 2016 by authors and Scientific Research Publishing Inc.

This work is licensed under the Creative Commons Attribution International License (CC BY).

http://creativecommons.org/licenses/by/4.0/

(c) (i) Open Access

\section{Abstract}

The study investigated genotypic and phenotypic co-efficients of variation, heritability, genetic advance at $5 \%$ selection intensity and in percentage of population mean of nine characters (plant height, leaf number, length and width of leaf lamina, number and weight of cormels per plant, weight of corm per plant, dry matter percentage in the tubers and tuber yield per from 14 cultivars of taro [Colocasia esculenta (L.) Schott]). Results indicated highest genotypic co-efficient of variation for dry matter percentage $(47.91)$, which was $95.78 \%$ of the phenotypic co-efficient of variation, whereas tuber yield per plant showed the widest range (819.37). Number of cormels per plant and dry matter percentage exhibited considerably higher heritability $(84.90 \%$ and $91.70 \%$, respectively) and genetic advance (81.19 and 79.00, respectively), indicating the potentiality of selection for improvement of such characters. These two characters were found to be positively correlated to tuber yield per plant. Path analysis revealed that weight of cormels per plant possessed the highest direct effect on tuber yield, indicating the importance of selection based on this character to increase tuber yield per plant.

\section{Keywords}

Character Association, Heritability, Genotypic Co-Efficient of Variation, Phenotypic Co-Efficient of Variation, Tuber Crop

\footnotetext{
${ }^{*}$ Corresponding author.
} 


\section{Introduction}

Taro [Colocasia esculenta (L.) Schott] is a herbaceous perennial tuber bearing plant belonging to the family Araceae, with enlarged corms acting as starch storage organs. It is believed to be one of the most ancient food crops [1] [2] and widely cultivated in several African and Asian countries. [3] estimated global production of taro to be 11.8 million tons per annum from approximately two million hectares with an average yield of about 6 tons/ha [4]. In India, taro is cultivated in virtually all the states, especially in the coastal belts of Tamil Nadu, Kerala, Andhra Pradesh, West Bengal, Bihar, certain parts of Uttar Pradesh as well as in a few northeastern states. There are several recognized cultivars of taro which can be categorized into two groups, namely,

1) Eddoe type (Colocasia esculenta var. antiquoroum);

2) Dasheen type (Colocasia esculenta var. esculenta).

To have a good choice of characters for selection of desirable genotypes under planned breeding program for higher yield, the knowledge of nature and magnitude of variation existing in available breeding materials, the association of component characters with yield and their exact contribution through direct and indirect effects are of crucial importance. Yield is a complex quantitative character and is the resultant of various component characters working together. Therefore, for understanding the effect of the components on yield, it is essential to know the association of different characters among themselves and with that of yield.

Path coefficient [5] analysis is conducted to elucidate association of various yield attributes and their contributions towards yield. [6] applied this method for the first time to plants in order to analyze the inter-correlation in a cause and effect system in crested wheat grass.

Several authors have reported a number of relationships among the yield attributing characters of taro. [7] observed mean weight of corme1s, number of cormels per plant and leaf area index (LAI) to be positively and significantly correlated with yield. [8] reported that the numbers of tillers and corme1s per plant had a significant correlation with corbel yield at phenotypic and genotypic levels. A comparative study of the genotypic, phenotypic and environmental correlation in taro by [9] revealed that the most important character contributing to yield is the number of cormels per plant. [10] reported yield per plant to be significantly and positively correlated with petiole length, leaf length, breadth and numbers, inflorescence length, spathe length and spathe breadth at the phenotypic level. They also reported yield per plant to be positively and significantly correlation with plant height and leaf numbers at genotypic level.

The current work aims to determine the association of yield with yield contributing characters and their direct and indirect effects on tuber yield of banda type (Colocasia esculenta var esculenta) of taro at the southern region of the state of West Bengal (India), to enrich the limited information that was available during the time of study on association among traits and their influences on yield for the above mentioned type of taro.

\section{Materials and Methods}

\subsection{Experimental Site}

The field experiment was conducted during April to November of 2001 at Mondouri Teaching Farm of Bidhan Chandra Krishi Viswavidyalaya (Bidhan Chandra Agricultural University) (BCKVV), Nadia, West Bengal, India. The experimental site was located in the sub-tropical region ( $23.5^{\circ} \mathrm{N}$ latitude and $89^{\circ} \mathrm{E}$ longitude), $9.75 \mathrm{~m}$ above the mean sea level. The experiment was conducted in an upland condition. The soil of the site was sandy loam in texture with good drainage and water holding capacity and it contained $0.076 \%$ total nitrogen, $0.002 \%$ available phosphorous and $0.274 \%$ total potassium.

\subsection{Experimental Materials}

The experimental materials included 14 cultivars of Colocasia esculenta, collected by the All India Coordinated Research Project (AICRP) on tuber crops, BCKVV branch. These cultivars were collected from Bihar, Uttar Pradesh, and West Bengal. The names and sources of these cultivars are presented in the Table 1.

\subsection{Experimental Materials}

The detail of the experimental layout is shown in the Table 2. Land was prepared using standard practices. 
Planting was conducted on April 7, 2001. Recommended cultural practices were adopted. Recording of morphological data started on May 7 and continued till October 7. Harvesting started on November 2 and continued up to November 5. Five plants were labeled randomly from each replication from which data were recorded. Observation on plant height, leaf number, length and breadth of leaf lamina were conducted at the early maturity stage of the plants (four months growth stage). Weight of corms and cormelsper plant, dry matter percentage in the tuber and tuber yield per plant were recorded at the seven months growth stage.

\subsubsection{Plant Height}

Plant height $(\mathrm{cm})$ was recorded from the soil to the top of the canopy of the plant without disturbing it.

Table 1. Names and sources of taro cultivars under study.

\begin{tabular}{ccc}
\hline Sl. No. & Cultivar & Source \\
\hline 1. & EAC-1 & Dihar Agricultural University (Ranchi, Jharkhand, India) \\
2. & EAC-2 & Do \\
3. & EAC-3 & Do \\
4. & EAC-6 & Do \\
5. & EAC-12 & Do \\
6. & EAC-20 & Do \\
7. & EAC-25 & Do \\
8. & EAC-26 & NDB-1 \\
9. & NDB-2 & Narendra Dev University of Agricuture and Technology (Faizabad, Uttar Pradesh, India) \\
10. & NDB-3 & Do \\
11. & GK-2 & Do \\
12. & GK-3 & NCC-13 \\
13 & & Nadia, West Bengal, India \\
14. & Do & Do \\
\hline
\end{tabular}

Table 2. Details of the experimental layout.

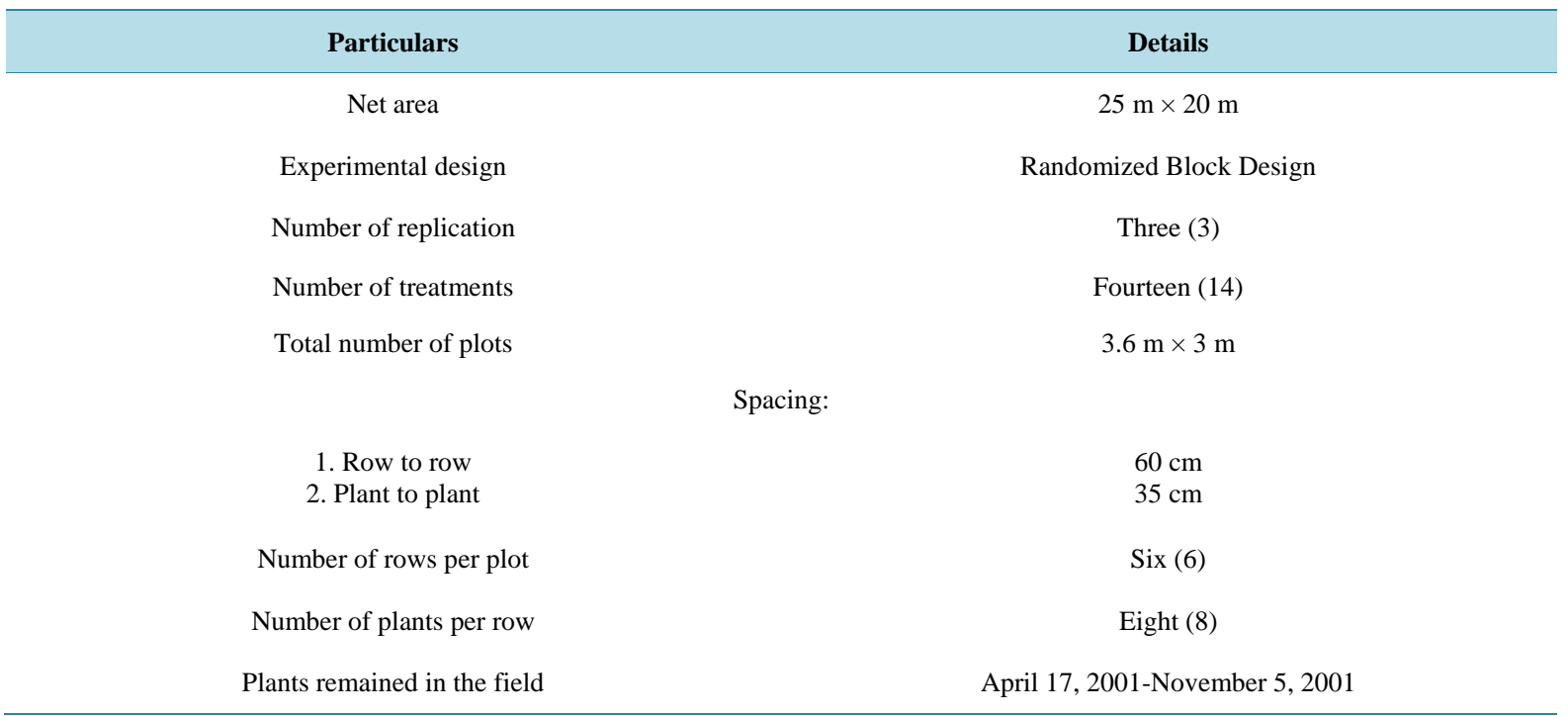




\subsubsection{Leaf Number}

The total number of leaves in a given plant was counted.

\subsubsection{Length of Leaf Lamina}

Leaf lamina length $(\mathrm{cm})$ was recorded at the maximum expansion from the tip of the lamina to portion of the basal lamina end of one side of its notch.

\subsubsection{Breadth of Leaf Lamina}

Leaf lamina breadth $(\mathrm{cm})$ was recorded at the maximum expansion of the lamina throughout the lamina and petiole junction.

\subsubsection{Number of Cormels per Plant}

The number of side tubers per plant was counted after harvesting.

\subsubsection{Weight of Corms per Plant}

The weight (g) of the mother tuber (corm) from individual plants was recorded after harvesting.

\subsubsection{Weight of Cormels per Plant}

The weight (g) of the side tubers (corm) from each plant was recorded after harvesting.

\subsubsection{Dry Matter Percentage in the Tubers}

One hundred grams of tuber was heated to $70^{\circ} \mathrm{C}$ in a drier and the weight of the dried tuber was recorded. Next, it was converted to percent (\%) basis, indicating dry matter percentage in the tuber.

\subsubsection{Tuber Yield per Plant}

The total weight (g) of corms and cormels per plant was recorded.

\subsection{Statistical Analysis}

Recorded data of different characters under study were subjected to the variance analysis appropriate to a randomized block design and the significance of different sources of variances were tested following standard procedures of F-tests at $5 \%$ and $1 \%$ levels of significance. The critical differences between the entries were calculated at 5\% level of significance. Genotypic, phenotypic and environmental variances $\left(\sigma_{g}^{2}, \sigma_{p}^{2}\right.$ and $\sigma_{e}^{2}$ respectively) and covariance were determined as described by [11]. Heritability (broad sense, $\mathrm{h}^{2}$ ) and genetic advance were calculated by the procedure described by [12] [13], respectively. Path coefficient analysis was conducted by the method given by [6].

\section{Results and Discussion}

Mean values of the various characters under study for the 14 cultivars of taro are shown in the Table 3 .

\subsection{Analysis of Variance (ANOVA)}

Analysis of variance for nine characters of taro under study is summarized in the Table 4 . The variance test ratios (F-value) were found to be significant for 5 characters in $1 \%$ level of significance. These characters were plant height, number of cormels per plant, weight of cormels per plant, drylmatter percentage and tuber yield per plant. The highest F-value was observed in dry matter percentage (104.96) and the lowest value was found in case of plant height (3.00). If the other characters are arranged according to the increasing order of F-value, they will be arranged as follows: tuber yield per plant (15.99), number of cormels per plant (17.85) and weight of cormels per plant (52.45). The character leaf number (2.17) was significant at $5 \%$ level of significance. The length and breadth of leaf lamina and weight of corm per plant were found to be non-significant. The F-values indicate the influence of environment on the character. The characters for which F-values were found to be significant were less influenced by environment. Leaf number was most highly influenced by environment and dry matter percentage was the least affected one. 
Table 3. Mean values of nine characters of 14 taro (Colocasia esculenta) cultivars.

\begin{tabular}{|c|c|c|c|c|c|c|c|c|c|c|}
\hline $\begin{array}{l}\text { Sl. } \\
\text { No. }\end{array}$ & Cultivar & $\begin{array}{l}\text { Plant } \\
\text { height } \\
\text { (cm) }\end{array}$ & $\begin{array}{l}\text { Leaf } \\
\text { number }\end{array}$ & $\begin{array}{l}\text { Length } \\
\text { of leaf } \\
\text { lamina } \\
(\mathrm{cm})\end{array}$ & $\begin{array}{c}\text { Breadth } \\
\text { of leaf } \\
\text { lamina } \\
(\mathrm{cm})\end{array}$ & $\begin{array}{l}\text { Number } \\
\text { of } \\
\text { cormels } \\
\text { per } \\
\text { plant }\end{array}$ & $\begin{array}{l}\text { Weight } \\
\text { of } \\
\text { corm } \\
\text { per } \\
\text { plant (g) }\end{array}$ & $\begin{array}{l}\text { Weight } \\
\text { of } \\
\text { cormels } \\
\text { per } \\
\text { plant (g) }\end{array}$ & $\begin{array}{c}\text { Dry } \\
\text { matter } \\
(\%)\end{array}$ & $\begin{array}{l}\text { Tuber } \\
\text { yield } \\
\text { per } \\
\text { plant } \\
\text { (g) }\end{array}$ \\
\hline 1. & EAC-1 & 89.95 & 6.93 & 45.94 & 34.74 & 6.40 & 580.09 & 654.18 & 29.67 & 1234.26 \\
\hline 2. & EAC-2 & 90.94 & 6.53 & 45.14 & 33.94 & 6.47 & 639.82 & 601.02 & 19.09 & 1240.84 \\
\hline 3. & EAC-3 & 88.93 & 7.20 & 44.87 & 35.47 & 0.00 & 764.78 & 0.00 & 22.50 & 764.78 \\
\hline 4. & EAC-6 & 86.93 & 7.47 & 47.39 & 37.48 & 6.60 & 655.34 & 796.24 & 18.05 & 1451.58 \\
\hline 5. & EAC-12 & 89.84 & 6.47 & 45.97 & 37.67 & 6.73 & 636.39 & 727.52 & 16.96 & 1363.93 \\
\hline 6. & EAC-20 & 90.61 & 5.60 & 48.29 & 37.43 & 6.20 & 611.09 & 680.70 & 11.93 & 1291.79 \\
\hline 7. & EAC-25 & 86.55 & 6.20 & 48.23 & 36.56 & 0.00 & 693.99 & 0.00 & 27.50 & 693.99 \\
\hline 8. & EAC-26 & 86.06 & 7.47 & 44.24 & 34.98 & 7.07 & 626.71 & 595,15 & 19.24 & 1221.86 \\
\hline 9. & NDB-1 & 86.37 & 6.13 & 46.21 & 35.98 & 5.67 & 602.20 & 486.61 & 23.75 & 1088.82 \\
\hline 10. & NDB-2 & 89.07 & 6.47 & 45.19 & 34.55 & 6.93 & 618.75 & 503.23 & 21.15 & 1122.05 \\
\hline 11. & NDB-3 & 87.63 & 6.53 & 43.91 & 36.38 & 6.40 & 647.52 & 627.14 & 26.94 & 1341.33 \\
\hline 12. & GK-2 & 83.45 & 6.13 & 44.27 & 36.61 & 6.67 & 599.21 & 493.83 & 20.06 & 1093.04 \\
\hline 13. & GK-3 & 80.77 & 7.13 & 43.43 & 34.15 & 4.73 & 609.24 & 540.43 & 23.15 & 1149.67 \\
\hline 14. & BCC-13 & 86.86 & 6.87 & 45.60 & 33.43 & 5.27 & 639.08 & 782.94 & 20.75 & 1513.31 \\
\hline
\end{tabular}

Table 4. Analysis of variance for nine characters of 14 taro (Colocasia esculenta) cultivars.

\begin{tabular}{|c|c|c|c|c|c|c|c|c|c|c|}
\hline \multirow[b]{2}{*}{ Source } & \multirow[b]{2}{*}{ df } & \multicolumn{9}{|c|}{ Mean Squares } \\
\hline & & Plant heigh & Leaf number & $\begin{array}{l}\text { Length of } \\
\text { leaf lamina }\end{array}$ & $\begin{array}{l}\text { Breadth of } \\
\text { leaf lamina }\end{array}$ & $\begin{array}{l}\text { Number of } \\
\text { cormals per } \\
\text { plant }\end{array}$ & $\begin{array}{l}\text { Weight of } \\
\text { corm per } \\
\text { plant }\end{array}$ & $\begin{array}{l}\text { Weight of } \\
\text { cormals per } \\
\text { plant }\end{array}$ & $\begin{array}{l}\text { Dry matter } \\
\text { percentage }\end{array}$ & $\begin{array}{c}\text { Tuber yield } \\
\text { per plant }\end{array}$ \\
\hline Replication & 2 & 25.65 & 0.69 & 8.10 & 3.42 & 1.54 & 200.00 & 4385.50 & 1.1601 & 6372.00 \\
\hline Variety & 13 & 24.02 & 0.90 & 6.95 & 5.89 & 16.74 & 6413.48 & $18,374.06$ & 22.75 & $16,015.60$ \\
\hline Error & 26 & 8.00 & 0.41 & 6.92 & 4.80 & 0.93 & 5300.48 & 3502.78 & 6.62 & $10,014.76$ \\
\hline E-Value & & $3.00^{* *}$ & $2.17^{*}$ & 1.00 & 1.22 & $17.85^{* *}$ & 1.20 & $52.45^{* * *}$ & $104.96^{* *}$ & $15.99^{* *}$ \\
\hline SE m $( \pm)$ & & 2.31 & 0.53 & 2.14 & 1.79 & 0.76 & 59.44 & 48.32 & 2.10 & 81.70 \\
\hline $\mathrm{CD}(0.05)$ & & 1.12 & 1.08 & 4.40 & 3.67 & 1.62 & 121.85 & 99.06 & 4.31 & 167.50 \\
\hline CV\% & & 3.23 & 9.70 & 5.77 & 6.14 & 18.05 & 11.42 & 11.06 & 14.37 & 8.45 \\
\hline
\end{tabular}

${ }^{*}$ and ${ }^{* *}$ indicate significance (p < 0.05 and 0.01, respectively). Abbreviations are as follows: df: Degrees of freedom; SEm ( \pm ): Standard error of mean; CD: Critical difference; CV: Coefficient of variation.

The standard error of mean [SEm $( \pm)$ ] value was estimated to be highest for the character of tuber yield per plant (81.70), followed by weight of corm per plant (59.44), weight of cormels per plant (48.32), plant height (2.31), length of leaf lamina (2.14), dry matter percentage (2.10), breadth of leaf lamina (1.78) and number of cormels per plant $(0.79)$. So the lowest stand and error of mean value was found in case of the number of cormels per plant.

Co-efficient of variation (CV) analysis indicates the consistency of the sample observed for recording data. If the value of co-efficient of variation is found to be more than $20 \%$, than the sample is considered to be less con- 
sistent. Here the co-efficient of variation values are less than $20 \%$ in all the characters studied. So samples for recording data for all the characters were consistent.

Wider the range, the more desirable is the character for selection. Widest range was observed in the tuber yield per plant where the range was 819.37. The next widest range was recorded in the character weight of cormels per plant. The range of this character was 796.24. The character weight of corms per plant showed considerably wide range (184.69). Other characters are less variable, their ranges are 10.17 for plant height, 7.07 for number of cormels per plant, for dry matter percentage, 4.86 in-case of length of leaf lamina and 4.24 in breadth of leaf lamina. The lowest range was found in case of leaf number (1.87). So it does not appear to be good as selection criteria.

\subsection{Assessment of Genotypic and Phenotypic Variability}

Table 5 represents the genotypic and phenotypic co-efficient of variation (GCV and PCV, respectively), heritability and genetic advance both at $5 \%$ selection intensity and as an expression of percentage of population mean of different characters of 14 Colocasia esculenta cultivars under study.

The highest PCV was observed in case of dry matter percentage and the value was 50.02, followed by the PCV value of weight of cormels per plant (47.14). The PCVs of other characters when arranged in an increasing order are 5.77 in case of length of leaf lamina, 6.37, for breadth of leaf lamina, 11.45 for leaf number 11.81 for weight of corm per plant 20.70 for tuber yield and 46.43 for number of cormels per plant. The lowest PCV value was found in case of plant height (4.18).

The highest GCV was also found in case of dry matter percentage (47.91) which was $95.78 \%$ of the PCV. The lowest GCV was observed in case of length of leaf lamina (0.20), being only 3.47\% of the PCV. The GCV values of other characters with their respective percentage of PCV are 1.74 for the breadth of leaf lamina (26.69\%),

Table 5. Mean, range and estimates of genetic variability among nine characters of 14 taro (Colocasia esculenta) cultivars.

\begin{tabular}{|c|c|c|c|c|c|c|c|c|}
\hline \multirow[b]{2}{*}{ Sl. No. } & \multirow[b]{2}{*}{ Character } & \multicolumn{2}{|c|}{ Co-efficient of Variation } & \multirow[b]{2}{*}{ Source } & \multirow[b]{2}{*}{ Mean } & \multirow{2}{*}{$\begin{array}{c}\text { Heritability } \\
\text { (\%) }\end{array}$} & \multirow{2}{*}{$\begin{array}{c}\text { Genetic } \\
\text { advance } \\
\text { (at } 5 \% \\
\text { selection } \\
\text { intensity) }\end{array}$} & \multirow{2}{*}{$\begin{array}{c}\text { Genetic } \\
\text { advance } \\
\text { (as \% of } \\
\text { population } \\
\text { mean) }\end{array}$} \\
\hline & & Genotypic & Phenotypic & & & & & \\
\hline 1. & Plant height & $\begin{array}{c}2.64 \\
(63.16)\end{array}$ & 4.18 & $\begin{array}{c}80.77-90.94 \\
10.17\end{array}$ & 87.43 & 40.00 & 3.01 & 3.44 \\
\hline 2. & $\begin{array}{c}\text { Leaf } \\
\text { number }\end{array}$ & $\begin{array}{c}6.08 \\
(53.10)\end{array}$ & 11.45 & $\begin{array}{c}5.60-7.47 \\
1.87\end{array}$ & 6.65 & 28.20 & 0.44 & 6.62 \\
\hline 3. & $\begin{array}{l}\text { Length } \\
\text { of leaf } \\
\text { lamina }\end{array}$ & $\begin{array}{c}0.20 \\
(3.47)\end{array}$ & 5.77 & $\begin{array}{c}43.43-48.29 \\
4.86\end{array}$ & 45.62 & 0.10 & 0.01 & 0.02 \\
\hline 4. & $\begin{array}{l}\text { Breadth of leaf } \\
\text { lamina }\end{array}$ & $\begin{array}{c}1.74 \\
(26.69)\end{array}$ & 6.37 & $\begin{array}{c}33.43-37.67 \\
4.24\end{array}$ & 35.67 & 7.10 & 0.33 & 0.93 \\
\hline 5. & $\begin{array}{c}\text { Number of } \\
\text { cormels per } \\
\text { plant }\end{array}$ & $\begin{array}{c}42.77 \\
(92.12)\end{array}$ & 46.43 & $\begin{array}{c}0.00-7.07 \\
7.07\end{array}$ & 5.37 & 84.90 & 4.36 & 81.19 \\
\hline 6. & $\begin{array}{c}\text { Weight of corn } \\
\text { per plant }\end{array}$ & $\begin{array}{c}3.02 \\
(25.57)\end{array}$ & 11.81 & $\begin{array}{c}580.09-764.78 \\
184.69\end{array}$ & 637.44 & 6.50 & 10.15 & 1.59 \\
\hline 7. & $\begin{array}{l}\text { Weight of cor- } \\
\text { mels per plant }\end{array}$ & $\begin{array}{c}45.82 \\
(97.79)\end{array}$ & 47.14 & $\begin{array}{c}0.00-796.24 \\
796.24\end{array}$ & 534.93 & 94.50 & 49.08 & 9.18 \\
\hline 8. & $\begin{array}{l}\text { Dry matter } \\
\text { percentage }\end{array}$ & $\begin{array}{c}47.91 \\
(95.78)\end{array}$ & 50.02 & $\begin{array}{c}11.96-29.67 \\
17.71\end{array}$ & 21.43 & 91.70 & 16.93 & 79.00 \\
\hline 9. & $\begin{array}{c}\text { Tuber yield per } \\
\text { plant }\end{array}$ & $\begin{array}{c}18.90 \\
(91.30)\end{array}$ & 20.70 & $\begin{array}{c}693.93-1513.31 \\
819.37\end{array}$ & 1183.67 & 83.30 & 42.00 & 3.55 \\
\hline
\end{tabular}

Values in the parentheses indicate genotypic co-efficient of variationtheir respective percentage of phenotypic co-efficient of variation. 
2.64 in plant height (63.16\%) 3.02 in case of weight of corms per plant (25.57\%), 6.08 for leaf number (53.10\%), 18.90 for tuber yield per plant (91.30\%), 42.77 in case of number of cormels per pant (92.12\%) and 45.82 for weight of cormels per plant (97.79\%). Values in the parenthesis indicate the percentage of GCV of PCV.

It has been found that the characters such as dry matter percentage, weight of cormels per plant and number of cormels per plant has quite high GCV values and also have a good share of respective PCV values. So it could be concluded that selection will be effective considering these characters.

The heritability (broad sense) was highest in the character weight of cormels per plant (94.50\%), but genetic advance for the same character at percent of population mean is very low (9.18). The same situation occurs in the case of the character tuber yield per plant, when heritability and genetic advance were $83.30 \%$ and 3.55 respectively. This condition of high heritability followed by low genetic advance indicates that the high heritability is expressed probably due to the favorable influence of environment rather than genotype and selection for such traits may not be rewarding.

In a number of characters both heritability and genetic advance are low. The heritability and genetic advance for the characters such as leaf number (28.20\%; 6.62), breadth of leaf lamina $(7.10 \%$; 0.93$)$; weight of corm per plant $(6.50 \%$; 1.59$)$ and length of leaf lamina where the lowest value was observed $(0.10 \%$; 0.02$)$. [The values in the parenthesis indicate the heritability and genetic advance of the characters respectively]. Low heritability followed by low genetic advance indicates that the character is highly influenced by environmental effects and selection for such character would be ineffective.

Both heritability and genetic advance are very high for number of cormels per plant (84.90\%; 81.19) and dry matter percentage (91.70\%; 79.00). Such high heritability followed by high genetic advance indicates that selection may be effective for improvement of such characters.

\subsection{Assessment of Character Association}

The intensity and direction of the association among the characters may be measured by genotypic $(G)$ and phenotypic (P) correlation depending on the types of material under .study and kind of experimental design used. Values for $\mathrm{G}$ and $\mathrm{P}$ among characters under study of 14 taro cultivars are presented in the Table 6. It is evident from the table that plant height did not show correlation with the other characters except for the breadth of leaf lamina at the genotypic level $\left(\mathrm{r}_{\mathrm{g}}=0.534\right)$. Leaf number had negative genotypic correlation with length of leaf lamina $\left(\mathrm{r}_{\mathrm{g}}=-1.415\right)$ and breadth of leaf lamina $\left(\mathrm{r}_{\mathrm{g}}=-1.517\right)$. The character length of leaf lamina had significant positive correlation with breadth at phenotypic level $\left(r_{p}=0.552\right)$ and its correlations with number of cormels per plant weight $\left(r_{g}=0.906\right)$, weight of corm per plant $\left(r_{g}=0.618\right)$, weight of cormels per plant $\left(r_{g}=0.627\right)$ and cormel yield per plant $\left(r_{\mathrm{g}}=1.288\right)$ at the genotypic level were observed. It had negative genotypic correlation with dry matter percentage $\left(r_{\mathrm{g}}=-0.710\right)$.

Breadth of leaf lamina also had positive genotypic correlation $\left(r_{g}=0.964\right)$ with weight of corm per plant. It was negatively correlated with dry matter percentage at genotypic level $\left(r_{g}=-0.576\right)$. Number of cormels per plant had highly significant and positive correlation at phenotypic level with weight of cormels per plant and it also had positive correlation at the genotypic level with the same character $\left(r_{p}=0.810, r_{g}=0.921\right)$ as well as dry matter percentage $\left(r_{p}=0.750, r_{g}=0.847\right)$ and tuber yield per plant $\left(r_{p}=0.678, r_{g}=0.862\right)$. Number of cormels per plant had negative genotypic correlation with weight of corm per plant $\left(r_{g}=-0.876\right)$. Weight of corm per plant was correlated with weight of cormels per plant in a negative direction at genotypic level $\left(r_{\mathrm{g}}=-0.800\right)$ and with tuber yield per plant, a genotypic correlation in the positive direction was observed $\left(r_{g}=0.969\right)$. Weight of cormels per plant was correlated in a highly significant way at the phenotypic level with dry matter percentage and in the genotypic level, a positive correlation with the same character also existed $\left(r_{p}=0.716, r_{g}=0.756\right)$. It also had a high significant, phenotypic correlation with tuber yield per plant $\left(r_{p}=0.865\right)$. Dry matter percentage was found to be correlated in a highly significant way with tuber yield per plant in the phenotypic level and in the genotypic level, a positive correlation with the same character was noted $\left(r_{p}=0.681, r_{g}=0.773\right)$.

From the correlation study, it is evident that if the number of cormels is increased, the cormel weight and tuber yield per plant will be increased as well. [8] also observed significant correlation of cormel number with yield. This result was further supported by the findings of [9] [14], who observed correlation between cormel number and tuber yield. Weight of cormels per plant, when increased, will also increase the tuber yield per plant This result is strongly confirmed by previous studies [8] [9] [14]. An increase in the dry matter content will also result in the increment of cormels weight. Tuber yield per plant will increase following an increase in the dry 
Table 6. Phenotypic and genotypic correlation among nine characters of 14 taro (Colocasia esculenta) cultivars.

\begin{tabular}{|c|c|c|c|c|c|c|c|c|c|}
\hline Characters & & $\begin{array}{l}\text { Leaf } \\
\text { number }\end{array}$ & $\begin{array}{l}\text { Length } \\
\text { of leaf } \\
\text { lamina }\end{array}$ & $\begin{array}{l}\text { Breadth of } \\
\text { leaf lamina }\end{array}$ & $\begin{array}{l}\text { Number of } \\
\text { cormals per } \\
\text { plant }\end{array}$ & $\begin{array}{c}\text { Weight of } \\
\text { corm per } \\
\text { plant }\end{array}$ & $\begin{array}{l}\text { Weight of } \\
\text { cormals per } \\
\text { plant }\end{array}$ & $\begin{array}{c}\text { Dry } \\
\text { matter } \\
\text { percentage }\end{array}$ & $\begin{array}{c}\text { Tuber } \\
\text { yield per } \\
\text { plant }\end{array}$ \\
\hline \multirow{2}{*}{ Plant height } & $\mathrm{P}$ & -0.175 & 0.258 & 0.002 & 0.007 & -0.081 & 0.074 & -0.079 & 0.145 \\
\hline & G & 0.338 & 0.291 & 0.534 & 0.162 & -0.212 & 0.127 & 0.195 & 0.133 \\
\hline \multirow{2}{*}{$\begin{array}{c}\text { Leaf } \\
\text { number }\end{array}$} & $\mathrm{P}$ & & -0.076 & -0.052 & -0.054 & 0.102 & 0.080 & 0.019 & 0.150 \\
\hline & G & & -1.415 & -1.517 & -0.028 & 0.327 & 0.091 & 0.195 & 0.157 \\
\hline $\begin{array}{c}\text { Lengthof } \\
\text { leaf }\end{array}$ & $\mathrm{P}$ & & & $0.552^{*}$ & 0.105 & 0.033 & -0.056 & -0.354 & -0.027 \\
\hline lamina & G & & & 0.399 & 0.906 & 0.618 & 0.627 & -0.710 & 1.288 \\
\hline $\begin{array}{l}\text { Breadth } \\
\text { of }\end{array}$ & $\mathrm{P}$ & & & & 0.108 & -0.156 & -0.039 & -0.228 & -0.130 \\
\hline $\begin{array}{l}\text { leaf } \\
\text { lamina }\end{array}$ & G & & & & 0.022 & 0.964 & 0.047 & -0.576 & 0.176 \\
\hline $\begin{array}{c}\text { Number } \\
\text { of }\end{array}$ & $\mathrm{P}$ & & & & & -0.377 & $0.810^{* *}$ & $0.750^{* *}$ & $0.678^{* *}$ \\
\hline $\begin{array}{l}\text { cormels } \\
\text { per } \\
\text { plant }\end{array}$ & G & & & & & -0.876 & 0.921 & 0.847 & 0.862 \\
\hline $\begin{array}{c}\text { Weight } \\
\text { of }\end{array}$ & $\mathrm{P}$ & & & & & & -0.220 & -0.159 & -0.076 \\
\hline $\begin{array}{l}\text { corm } \\
\text { per } \\
\text { plant }\end{array}$ & G & & & & & & -0.800 & -0.516 & 0.969 \\
\hline $\begin{array}{c}\text { Weight } \\
\text { of }\end{array}$ & $\mathrm{P}$ & & & & & & & $0.716^{* *}$ & $0.865^{* *}$ \\
\hline $\begin{array}{l}\text { cormels } \\
\text { per } \\
\text { plant }\end{array}$ & G & & & & & & & 0.756 & 0.057 \\
\hline $\begin{array}{c}\text { Dry } \\
\text { matter }\end{array}$ & $\mathrm{P}$ & & & & & & & & $0.681^{* * *}$ \\
\hline percentage & G & & & & & & & & 0.773 \\
\hline
\end{tabular}

Abbreviations are as follows: P: Phenotypic correlation; G: Genotypic correlation. All other abbreviations and notations are as in the Table 4.

matter percentage.

\subsection{Assessment of Cause and Effect}

It is not possible to establish the cause and effect relationship from the study of correlation as the resultant correlations are the products of interacting characters influencing each other. Phenotypic correlation of the characters were then partitioned in path co-efficient (Table 7), with a view to identify important characters having direct effect on tuber yield.

Perusal of direct and indirect effects from path analysis, only weight of cormels per plant showed high direct effect on tuber yield per plant (1.061). Weight of cormels per plant also showed highly significant positive correlation with tuber yield per plant $\left(r_{p}=0.865\right)$. Yield attributes like number of cormels per plant and weight of corm per plant showed very little direct effect on tuber yield per plant. Other characters such as plant height, leaf number, length and breadth of leaf lamina, dry matter percentage etc. showed negligible direct effects on tuber yield per plant.

From this study, it is evident that weight of cormels per plant significantly contributes most to tuber yield per plant. Further very low residual value (0.0828) reveals no other important character left for this analysis. It is evident from the residual value that the characters studied account for about $92 \%$ for yield. So, it can be safely concluded that weight of cormels per plant is the most important character controlling tuber yield per plant among the genotypes studied. 
Table 7. Phenotypic path analysis for nine characters of taro cultivars under study.

\begin{tabular}{|c|c|c|c|c|c|c|c|c|c|}
\hline Characters & $\begin{array}{l}\text { Plant } \\
\text { height }\end{array}$ & $\begin{array}{l}\text { Leaf } \\
\text { number }\end{array}$ & $\begin{array}{l}\text { Length of } \\
\text { leaf lamina }\end{array}$ & $\begin{array}{l}\text { Breadth of } \\
\text { leaf lamina }\end{array}$ & $\begin{array}{c}\text { Number of } \\
\text { cormels per } \\
\text { plant }\end{array}$ & $\begin{array}{c}\text { Weight of } \\
\text { corm per } \\
\text { plant }\end{array}$ & $\begin{array}{l}\text { Weight of } \\
\text { cormels per } \\
\text { plant }\end{array}$ & $\begin{array}{c}\text { Dry } \\
\text { matter } \\
\text { percentage }\end{array}$ & $\begin{array}{l}\text { Phenotypic } \\
\text { correlation with } \\
\text { tuber yield per } \\
\text { plant }\end{array}$ \\
\hline Plant height & 0.067 & -0.011 & 0.013 & 0.000 & -0.001 & -0.008 & 0.079 & 0.006 & 0.145 \\
\hline $\begin{array}{l}\text { Leaf } \\
\text { number }\end{array}$ & -0.012 & 0.062 & -0.004 & 0.006 & 0.004 & 0.010 & 0.085 & -0.001 & 0.150 \\
\hline $\begin{array}{l}\text { Length of leaf } \\
\text { lamina }\end{array}$ & 0.017 & -0.005 & 0.051 & -0.063 & 0.008 & -0.003 & -0.059 & 0.026 & 0.027 \\
\hline $\begin{array}{l}\text { Breadth of } \\
\text { leaf lamina }\end{array}$ & 0.000 & -0.003 & 0.028 & -0.114 & -0.001 & -0.015 & -0.041 & 0.017 & 0.130 \\
\hline $\begin{array}{l}\text { Number of } \\
\text { cormels per plant }\end{array}$ & 0.000 & -0.003 & -0.005 & -0.002 & -0.080 & -0.037 & 0.859 & -0.055 & $0.678^{* *}$ \\
\hline $\begin{array}{l}\text { Weight of } \\
\text { corm per plant }\end{array}$ & -0.005 & 0.006 & -0.002 & 0.018 & 0.030 & 0.098 & -0.233 & 0.012 & -0.076 \\
\hline $\begin{array}{l}\text { Weight of } \\
\text { cormels per plant }\end{array}$ & 0.005 & 0.005 & -0.003 & 0.004 & -0.065 & -0.022 & 1.061 & -0.052 & $0.865^{* *}$ \\
\hline $\begin{array}{c}\text { Dry } \\
\text { matter percentage }\end{array}$ & -0.005 & 0.001 & -0.018 & 0.026 & -0.060 & -0.016 & 0.760 & -0.073 & $0.681^{* *}$ \\
\hline
\end{tabular}

Residual effect = 0.0828; Bold diagonals indicate the direct effect. Other notation is as in the Table 4.

The results are supported by the findings of [8], who reported maximum direct effect towards yield for mean weight of cormels. It has also been observed that the weight of cormels per plant to have high direct effect towards yield [14].

From this analysis it is evident that weight of cormels per plant has got the highest direct effect on tuber yield per plant. The direct effects of other characters as well as their indirect effects via other characters are negligible. So in case of increasing the tuber yield per plant, top priority should be given on selection based on the weight of cormels per plant.

\section{Conclusion}

Character association and path-coefficient analyses have been conducted on several agronomic and horticultural crops, such as rice [14], maize [15] and tomato [16]. However, genetic analyses for the improvement of taro in the region where the study was conducted had not been performed before. It was found that selection would potentially be rewarding for the improvement of the character dry matter percentage, as the highest GCV was recorded for this character, which also had a good share of the respective PCV. High heritability and genetic advance values also indicated that selection may be effective for improvement of the above mentioned character. Path analysis showed that selection should be based on weight of cormels per plant to increase the total tuber yield. The work indicated the need for identification of the entire yield attributing characters of the crop.

\section{Acknowledgements}

We greatly acknowledge the All India Coordinated Research Project (AICRP) on tuber crops, BCKVV branch.

\section{References}

[1] Barrau, J. (1965) Histoire etpréhistoirehorticoles de I’Océanietropicale. Journal de la Société des Océanistes, 21, 5-78. 
[2] Plucknett, D.L. (1976) Edible Aroids: Alocasia, Colocasia, Cyrtosperma, Xanthosoma Evolution of Crop Plants. NW Simmonds, 10-12.

[3] Vishnu, S.N., Muthukrishnan, S., Vinaiyaka, M.H., Muthulekshmi, L.J., Raj, S.M., Syamala, S.V. and Mithun, R. (2012) Genetic Diversity of Phytophthoracolocasiae Isolates in India Based on AFLP Analysis. 3 Biotech.

[4] Singh, D., Jackson, G., Hunter, D., Fullerton, R., Lebot, V., Taylor, M., Iosefa, T., Okpul, T. and Tyson, J. (2012) Taro Leaf Blight-A Threat to Food Security. Agriculture, 2, 182-203. http://dx.doi.org/10.3390/agriculture2030182

[5] Wright, S. (1921) Correlation and Causation. Journal of Agricultural Research, 20, 557-585.

[6] Dewey, D.I. and Lu, K.H. (1959) A Correlation and Path-Coefficient Analysis of Components of Crested Wheatgrass Seed Production. Agronomy Journal, 51, 515-518. http://dx.doi.org/10.2134/agronj1959.00021962005100090002x

[7] Mohankumar, C.R., Saraswathy, P. and Sadanandan, N. (1990) Correlation and Path Analysis on Yield and Yield Components in Taro. Journal of Root Crops, 16, 140-141.

[8] Sarkar, S.K., Kumar, R. and Jain, B.P. (1996) Correlation and Path Coefficient Analysis on Yield and Yield Components of Colocasia esculenta (L.) Schott. Tropical Tuber Crops: Problems, Prospects and Future Strategies, 169.

[9] Thankamma Pillai, P.K., Lekshmi, K.R. and Sheele, M.N. (1995) Correlation and Path Analysis in Taro. Journal of Root Crops, 21, 86-89.

[10] Paul, K.K., Bari, M.A. and Debnath, S.C. (2010) Correlation and Path Coefficient Studies for Plant Characters in Aqua Aroids, Colocasia esculenta (L.) Schott. Journal of Scientific Research, 3, 169-176. http://dx.doi.org/10.3329/jsr.v3i1.6078

[11] Singh, R.K. and Chaudhary, B.D. (1979) Biometrical Methods in Quantitative Genetic Analysis. Biometrical Methods in Quantitative Genetic Analysis.

[12] Burton, G.W. and de Vane, E.H. (1953) Estimating Heritability in Tall Fescue (Festuca arundincea) from Replicated Clonal Material. Agronomy Journal, 45, 474-481. http://dx.doi.org/10.2134/agronj1953.00021962004500100005x

[13] Johnson, H.W., Robinson, H.F. and Comstock, R.E. (1955) Estimates of Genetic and Environmental Variability in Soybeans. Agronomy Journal, 47, 314-318. http://dx.doi.org/10.2134/agronj1955.00021962004700070009x

[14] Ansari, A., Julfiquar, A.W., Rasul, M.G., Hasan, M.J. and Rahman, M.M. (2010) Genetic Parameter, Correlation and Path Analysis for Yield and Yield Related Traits in Some Maintainer Lines of Hybrid Rice (Oryza sativa L). Eco-Friendly Agriculture Journal, 3, 89-95.

[15] Adesoji, A.G., Abubakar, I.U. and Labe, D.A. (2015) Character Association and Path Coefficient Analysis of Maize (Zea mays L.) Grown under Incorporated Legumes and Nitrogen. Journal of Agronomy, 14, 158. http://dx.doi.org/10.3923/ja.2015.158.163

[16] Islam, B.M.R., Ivy, N.A., Rasul, M.G. and Zakaria, M. (2010) Character Association and Path Analysis of Exotic Tomato (Solanum lycopersicum L.) Genotypes. Bangladesh Journal of Plant Breeding and Genetics, 23, 13-18. 